\title{
A new mastixioid florula from tektite-bearing deposits in South Bohemia, Czech Republic (Middle Miocene, Vrábče Member)
}

\author{
JOSEF ŠEVČ́́K, ZLATKO KVAČEK \& DIETER H. MAI
}

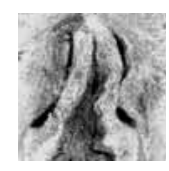

\begin{abstract}
A mastixioid assemblage consisting of seed cones of Pinus hampeana and fruits of Carya globosa, Diplopanax limnophilus and Eomastixia saxonica has been recovered in tektite-bearing deposits at Dobrkovská Lhotka near Trhové Sviny on the southern periphery of the České Budějovice Basin, South Bohemia. Although its diversity is low, the assemblage is characteristic enough to be correlated with the Middle Miocene floras of the Central Paratethys area (Wieliczka at Kraków - Middle Badenian) and with comparable floras in the Boreal Province (Kleinleipisch and Klettwitz Floral Assemblages in Germany - Middle Miocene). The obtained data corroborate the Badenian age for the Vrábče Member, the oldest tektite-bearing unit from where the fossils were collected (?the basal part of the Domanín Formation) and prove a short time span between the rain of tektites (Ries event, 15-14.5 Ma) and the deposition of this unit. $\bullet$ Key words: carpology, mastixioids, South Bohemia, Middle Miocene, Ries event.
\end{abstract}

ŠEVČíK, J., KVAČEK, Z. \& MAI, D.H. 2007. A new mastixioid florula from tektite-bearing deposits in South Bohemia, Czech Republic (Middle Miocene, Vrábče Member). Bulletin of Geosciences 82(4), 429-426 (3 figures). Czech Geological Survey, Prague. ISSN 1214-1119. Manuscript received Febuary 7, 2007; accepted in revised form September 17, 2007; issued December 31, 2007. • DOI 10.3140/bull.geosci.2007.04.429

Josef Ševčik, GEKON s.r.o., Na Jarově 2, 13000 Praha 3, Czech Republic; sevcikjosef@volny.cz・Zlatko Kvaček, Charles University, Institute of Geology and Palaeontology, Albertov 6, 12843 Praha 2, Czech Republic; kvacek@natur.cuni.cz・Dieter H. Mai, Naturkundemuseum der Humboldt Universität zu Berlin, Forschungsinstitut, Invalidenstrasse 43, D-10115 Berlin, Germany

South Bohemia was intensively explored geologically after the Second World War in respect of the extent and age of continental deposits concentrated in the Třeboň and České Budějovice basins and reaching across the state boundary to Austria (for review see Malecha 1985, Huber 2003). On the basis of palaeobotanical evidence, the greatest part of the basins fill named the Klikov Formation was recognized as a Late Cretaceous deposit (Němejc 1956, Pacltová 1961, Malecha et al. 1962). The age of the succeeding Lipnice Formation is so far uncertain, but perhaps is also Late Cretaceous (Němejc 1962, Malkovský 1995). The remaining formations of Neogene age have been divided into the Zliv, Mydlovary, Domanín and Ledenice formations (Fig. 1).

For more than two centuries, famous tektites, called "moldavites", created during the impact that created the Ries crater in southeastern Germany, have been collected in South Bohemia in gravels and sands assigned variously to the Miocene, Pliocene, as well as the Quaternary surface cover (Bouška 1972). In this account, new palaeobotanical evidence is presented concerning the age of the basal coarse-grained tektite-bearing deposit, the Vrábče Member (or Beds) sensu Žebera (1967). In view of the limited distri- bution of the fossiliferous horizon with the recovered plant fossils, the age determination cannot be generalized for all tektite-bearing deposits in South Bohemia, which accumulated over a much longer period of time. Still, this discovery offers new biostratigraphical data and correlation possibilities additional to the age determination obtained for the tektites by radiometric dating.

\section{Geological setting of tektite-bearing sediments in South Bohemia}

Attempts to fix the stratigraphical position of various tektite-bearing sediments in South Bohemia have so far relied on correlations with palaeontologically characterized lithostratigraphical units, namely the Mydlovary, Domanín and Ledenice formations. The time span of the tektite rain has been estimated based on the radiometric dating of the tektites as 15-14.5 Ma (Genter et al. 1967), which corresponds well with the age of impact glasses from the Ries crater (Genter et al. 1969). The re-deposition of tektites then occurred after this time in the Middle Miocene (Langhian) 
Figure 1. Chrono- and lithostratigraphy of the South Bohemian (České Budějovice and Třeboň basins) with important palaeontological sites ( ${ }^{1}$ Pacltová $1963 ;{ }^{2}$ this paper; ${ }^{3}$ Knobloch \& Kvaček $1996 ;{ }^{4}$ Němejc 1962 ; ${ }^{5}$ Němejc 1956, Pacltová 1961, Němejc \& Kvaček 1975, Mai \& Knobloch 1986; ${ }^{6}$ Fejfar 1989, personal communication 2007).

\begin{tabular}{|c|c|c|c|}
\hline Chronostrat. & Lithostratigraphy & $\begin{array}{c}\text { Palaeobotanical } \\
\text { sites }\end{array}$ & $\begin{array}{l}\text { Mammal } \\
\text { sites }\end{array}$ \\
\hline $\begin{array}{l}\text { Late Pliocene } \\
\text { to Pleistocene }\end{array}$ & $\begin{array}{r}\text { Kamenný Újezd } \\
\text { Gravel } \\
\text { Koroseky Sandy } \\
\text { Gravel }\end{array}$ & & \\
\hline Pliocene & Ledenice Fm. & Ledenice $^{1}$ & \\
\hline \multirow{4}{*}{$\begin{array}{l}\text { Middle } \\
\text { Miocene }\end{array}$} & Domanín Fm. & & $\begin{array}{l}\text { Lišov } \\
(\mathrm{MN7}-8)^{6}\end{array}$ \\
\hline & Vrábče Mb. & $\begin{array}{l}\text { Dobrkovská } \\
\text { Lhotka }^{2}\end{array}$ & \\
\hline & \multirow[b]{2}{*}{ Mydlovary Fm. } & Mydlovary $^{3}$ & $\begin{array}{l}\text { Lomnice/L. } \\
\text { (MN6) }^{6}\end{array}$ \\
\hline & & $\begin{array}{l}\text { Hluboká, } \\
\text { Kamenný } \\
\text { Újezd }^{3}\end{array}$ & $\begin{array}{l}\text { Strakonice } \\
(\mathrm{MN} 5)^{6}\end{array}$ \\
\hline Early Miocene & Zliv Fm. & Nová Reka ${ }^{3}$ & \\
\hline$?$ & Lipnice Fm. & Lipnice $^{4}$ & \\
\hline $\begin{array}{l}\text { Coniacian } \\
\text {-Santonian }\end{array}$ & Klikov Fm. & Klikov, Zliv ${ }^{5}$ & \\
\hline
\end{tabular}

onto the peneplain of weathered crystalline rocks and previous basin deposits including the Mydlovary Formation, from where the tektites have not been found. Tektites were transported into matrix sediments from wider surroundings stepwise together with clastic particles. This process occurred at different places at different time intervals. Some tektites were obviously reworked several times. Bouška (1972) recognized four types of tektite-bearing deposits:

A. The oldest type (according to Bouška 1972, "Upper" Miocene, i.e. the Middle Miocene in today's time scale) forms fills transported from a short distance into local depressions ("strew-field" sites). The deposits are at a low degree selected or not selected at all, clastic particles are angular, rarely sub-angular; the clay component is montmorillonitic.

B. Younger deposits of Pliocene to Pleistocene age originated in the time interval, when the hydrographical communication with the Alpine-Carpathian system was interrupted and South Bohemia was drained to the north. They consist of fluvio-lacustrine sediments with grains sub-ovoid and ovoid due to the length of transport. At places they contain kaolinitic sands with sub-angular grains; the clay content is kaolinitic or illitic. These gravels and sands are characteristically rusty in colour, probably due to admixtures of reworked soil, e.g., the Kroclov red soil (Žebera 1967). The tektites present there are often pebble-shaped, once more corroded and sharply sculptured and lustrous.

C. Quaternary not sorted slope loams and detritus contain angular tektites not showing a long transport.
D. Alluvial Late Quaternary to Recent deposits of streams yielding oval tektites with dull worn surface.

Žebera (1967) assumed a Miocene age for the oldest-tektite bearing deposits. On the basis of the lithological and stratigraphical data he established the Vrábče Member ("Beds"), Koroseky Sandy Gravel and Kamenný Újezd Gravel, which he ranged without palaeontological evidence into the Miocene to Pliocene.

The Mydlovary Formation dated to the KarpatianLower Badenian by fauna (Čtyroký \& Fejfar 1962; Fejfar

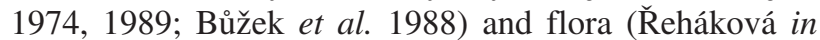
Vrána et al. 1980, Knobloch \& Kvaček 1996) does not contain tektites. The Domanín Formation was established on

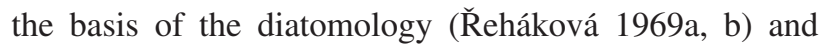
dated into the Middle Miocene (Upper Badenian to Sarmatian) on account of the correlation with similar diatom assemblages in the Handlová Basin in the Central Paratethys (Řeháková 1980). The tektite-rich Vrábče Member is assumed to represent the lateral equivalent of the basal part of the Domanín Formation (Bouška 1972). The Ledenice Formation has been dated as Pliocene on the basis of palynological and diatomological data (Pacltová 1963, Řeháková 1963) and lacks tektites. The Koroseky Sandy Gravel and Kamenný Újezd Gravel containing tektites are considered to be latest Pliocene (Romanian) without any palaeontological evidence on the basis of the regional geology (Bouška 1972).

Although the tektite-bearing deposits often contain irregularly distributed lenses of grey clay, almost no palynological data have been obtained from them, because the organic matter is fully oxidized in these kaolinitic sediments. Nevertheless, core samples at Besednice contained indeterminable trilete spores, isolated fragments of saccate pollen of the Pinaceae, rare fungi and tissue fragments (Jankovská in Ševčík 1980). The carbonized plant remains described below are the first macrofossils, which, together with wood pieces, contribute to the dating of the Vrábče Member.

\section{Material and methods}

The described fossil plant remains were recovered in 2003 and later in excavations for tektites near Dobrkovská Lhotka on the southern periphery of the České Budějovice Basin (coordinates 48 $47^{\prime} 15^{\prime \prime} \mathrm{N}$; 14 $4^{\circ} 37^{\prime} 10^{\prime \prime} \mathrm{E}-$ Fig. 2). The fossiliferous layers were only temporarily exposed and only the most apparent fossils were picked up by amateur collectors from the sediment without any attempt at washing, sieving and searching for small-sized fractions. The material consists of dark brown three-dimensionally preserved and only a little compressed carbonized seed cones and fruits; these can be sectioned, in our case by thin dental cutting discs. 


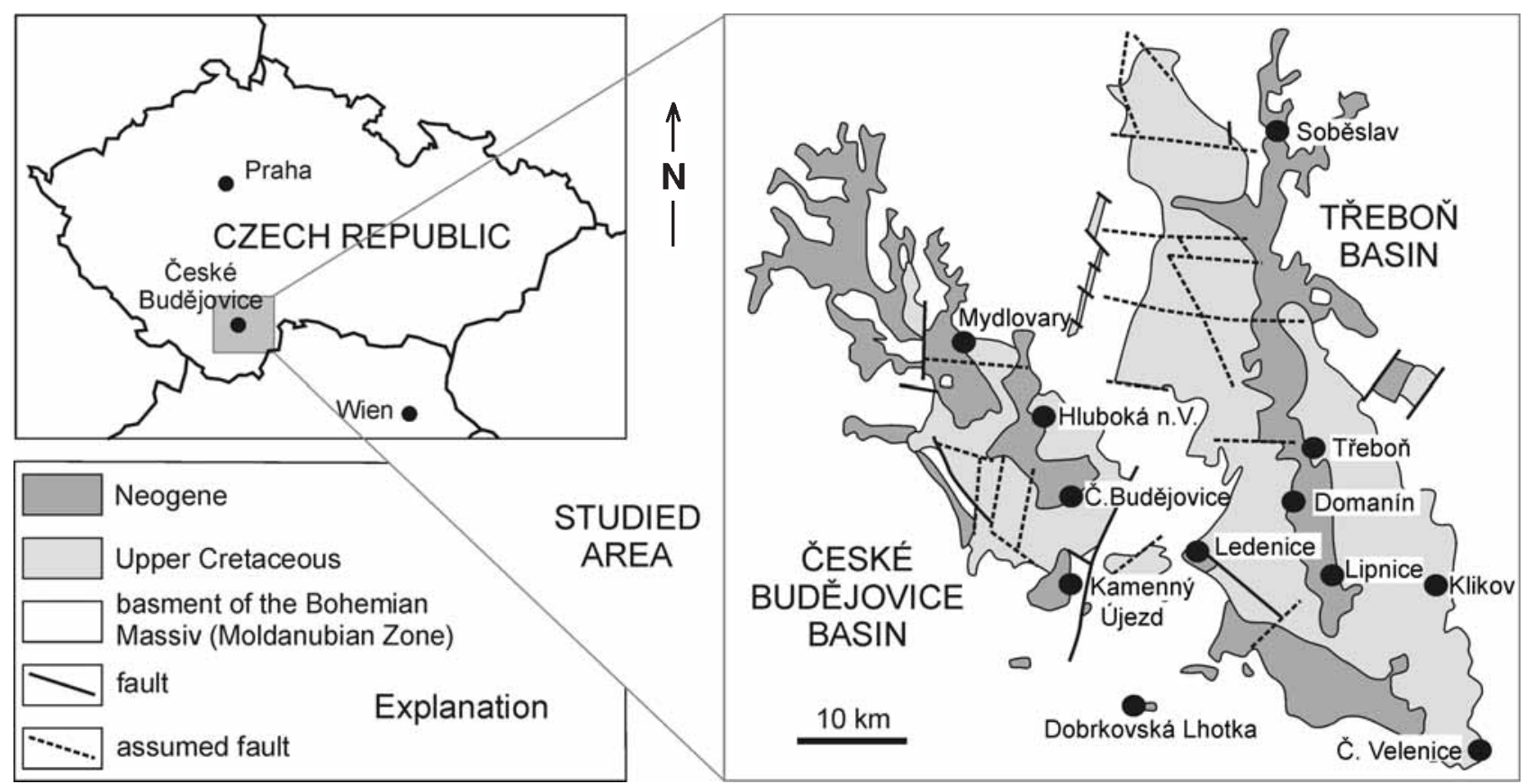

Figure 2. Geographic position of the described florula near Dobrkovská Lhotka within the Czech Republic and a detailed map of the České Budějovice and Třeboň basins (Slánská 1974, adapted).

At the site, the tektite-bearing deposits form irregular fills in depressions in the crystalline basement. The fossiliferous layers were unfortunately much disturbed by illegal search for tektites and, therefore, the exact position of the described plant fossils cannot be exactly fixed within the two sections obtained during the excavations.

The first section contains (from the earth surface down) layers of the following thickness:

$0.1-0.2 \mathrm{~m}$ - humic soil or peat;

1.0-1.5 m - sandy clay to fine-grained clayey sand ochre grey to brown;

$0.2 \mathrm{~m}$ - quartzose gravel with pebbles up to $2 \mathrm{~cm}$ across, very pure, with tektites;

$1.0 \mathrm{~m}$ - fine-grained sand grey to dark grey with clay admixture;

$1.0 \mathrm{~m}$ - sandy gravel with tektites, carbonized wood (pieces up to $15 \mathrm{~cm}$ large), carbonized plant fragments and fruits (the layer continued downwards, but further digging was prevented by strongly inflowing groundwater).

The second section not far from the former contains a similar sequence of deposits from the earth surface:

$0.0-0.5 \mathrm{~m}$ - soil with large tektites;

$0.5-1.1 \mathrm{~m}-$ fine-grained sand with small, nicely sculptured tektites;

1.1-6.0 m - strongly clayey sandy gravel, grey, with rounded tektites. The biggest specimens occur in the coarsegrained roof of this layer. The deeper part of the layer contains two horizons of sand $5-10 \mathrm{~cm}$ and $10-15 \mathrm{~cm}$ thick, respectively, with organic fragments. The lower one at the depth of $5.5 \mathrm{~m}$ probably yielded most of the described fossils. The layer continued downwards but again, further digging was prevented by groundwater.

In both pits the fossils were recovered by workmen who noticed these objects and some collected and passed them over to the first author. The sites are no longer accessible so that additional sampling is now impossible.

The recovered fossils are mostly housed in the collections of the palaeontological department, National $\mathrm{Mu}-$ seum, Prague (NM G); a smaller part has been returned to private collectors.

\section{Systematic descriptions}

Family Pinaceae

Pinus L.

\section{Subgenus Pinus}

\section{Pinus hampeana (Unger) Heer} Figure 3A, B

1847 Pitys hampeana Unger, p. 76, pl. 20, figs 1-3.

1855 Pinus hampeana (Unger) Heer, p. 56, pl. 20, fig. 4.

Material. - Two carbonized fragmentary seed cones (NM G 8540 and private coll.). 
Description. - Seed cones narrow ovoid to cylindrical, more than $40 \mathrm{~mm}$ long and 15-18 mm wide, symmetrical, cone scales thin, mostly broken at ends, finely striated along their length, obviously less than 100 per cone, apophyses almost flat to slightly domed, umbo poorly preserved, probably sub-vallat, excentromucronate (details of apophyses worn by transport processes).

Notes. - This pine was widespread in the Middle Miocene of Central Europe. The specimens at hand correspond well to the figures of the syntypes from Hauenstein, Styria (Unger 1841-1847) but this type material seems to be missing. Pinus hampeana occurs commonly at late Early and Middle Miocene sites in Germany (Wiesa, Klettwitz) and Poland (Turów) including the Middle Badenian of Wieliczka (see Zablocki 1928 - as Pinus polonica, Mai 1986, 1999). It is known from the Upper Miocene and Pliocene in northern Italy together with several Miocene thermophilic angiosperms (Berger 1958, Fischer \& Butzmann 2006).

Family Juglandaceae

Tribe Hicoreae

\section{Carya Nutt.}

\section{Carya globosa (Ludwig) Mädler}

Figure 3C-F

1857 Juglans globosa Ludwig, p. 103, pl. 21, fig. 12.

1939 Carya globosa (Ludwig) Mädler, p. 67, pl. 6, figs 6-8, text-fig. 20.

1942 Carya hauffei Kirchheimer, p. 424, pro parte, fig. 5 (non fig. 6).

Material. - Four nuts mostly split into halves (NM G 8541a, b, 8542, two specimens in private coll.).

Description. - Nuts ovoid to slightly obovoid, 18-44 mm long, 14-20 mm wide, at apex rounded or very shortly pointed, at base rounded, thick-walled, on surface coarsely longitudinally striated, striae often forked, lacunae in shale walls indistinct, secondary septa present, wide and short.
Notes. - According to the fruit morphology Carya globosa belongs to the group of the extant Carya aquatica (F. Michx.) Nutt. from SE North America (Mädler 1939, Kirchheimer 1957, Manchester 1987). Manchester (1987) correctly merged Carya globosa with similar Miocene fruits from Germany called C. hauffei Kirchheimer (1942, pro parte, only fig. 5 from Wiesa). This concept was partly accepted (Mai 2001), however, Mai $(1964,1999)$ and Czaja (2003) maintained $C$. hauffei sensu lato according to Kirchheimer $(1942,1957)$. The controversy in taxonomy should be solved by a thorough study based on the type specimens and variation and biostatistics of collections larger than we have.

Family Cornaceae

Subfamily Mastixioideae

\section{Diplopanax Handel-Mazzetti}

\section{Diplopanax limnophilus (Unger) Czaja}

Figure 3G-J

1850 Quercus limnophila Unger, p. 319, pl. 35, figs 1, 2.

1941 Mastixicarpum limnophilum (Unger) Kirchheimer, p. 614 , figs 7,8 .

2003 Diplopanax limnophilus (Unger) Czaja, p. 75, pl. 13, figs 12,13 .

Material. - Three completely carbonized stone fruits (NM G 8543-8545).

Description. - Stone fruits cylindrical-ovoid, 34-36 mm long and 12 to $20 \mathrm{~mm}$ in diameter, rounded at base, rounded or shortly pointed at apex, bilaterally symmetrical in cross section, unilocular, dorsally slightly flattened, ventrally convex, pericarp fully fused with endocarp, partly abraded, irregularly striated on the surface, endocarp mighty, ca $4 \mathrm{~mm}$ thick, with lacunae inside near outer surface, locule horseshoe-shaped in cross section, $10 \mathrm{~mm}$ high and $5 \mathrm{~mm}$ wide (in the specimen cut across), valve triangular in cross section, on the fruit surface not visible.

Notes. - These fruits known more commonly as Mastixicarpum limnophilum were recognized as members of the Masti-

Figure 3. Plant fossils from Dobrkovská Lhotka, Vrábče Member, Middle Miocene. • A, B - Pinus hampeana (Unger) Heer. A - abraded seed cone, NM G 8540. B - detail of cone scales, same specimen. $\bullet$ C-F - Carya globosa (Ludwig) Mädler. C - one half of a bigger fruit from outside, NM G 8541 a. D - same specimen from inside. E - half of a small split fruit from inside, NM G 8542 . F - same specimen from outside • G-J - Diplopanax limnophilus (Unger) Czaja. G - slender fruit with rounded apex and base, abraded on surface, NM G 8543. H - reverse side of the same. I - cross section of a fruit showing locule and wedge-shaped valve, NM G 8544. J - fruit with pointed apex and abraded surface, NM G 8545. $•$ K-M Eomastixia saxonica (Menzel) Holý. K - isodiametric flattened fruit with complete smooth epicarp, NM G 8546. L - fruit showing coarse sculpture of endocarp, NM G 8547. M - reverse side of the same. $\cdot$ Scale bars $=5 \mathrm{~mm}$ 
Josef Ševčík et al. • A new mastixioid florula from tektite-bearing deposits, South Bohemia
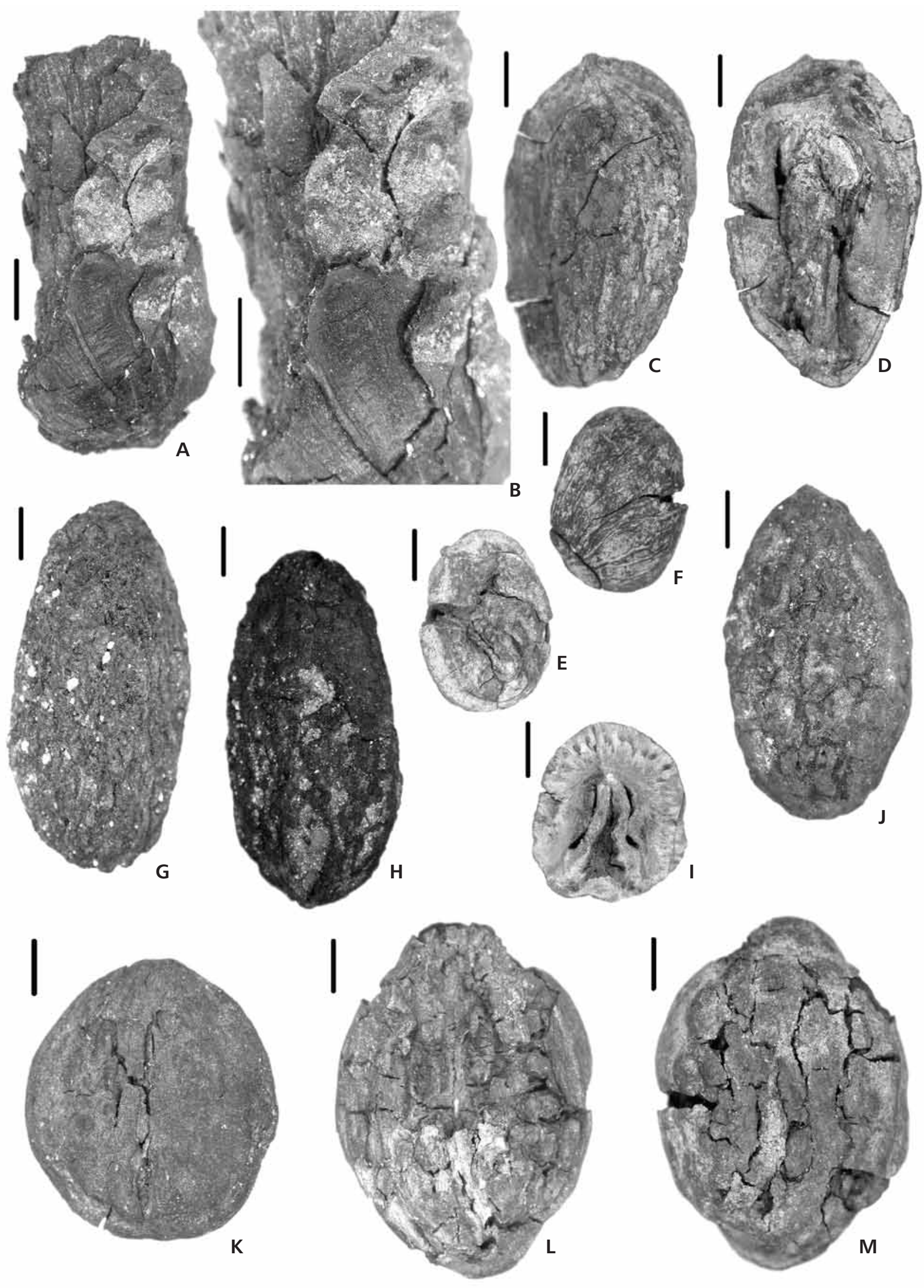
xioideae by Kirchheimer (1941, 1957), who referred them to the extinct genus Mastixicarpum Chandler. The fossils were at first misinterpreted as acorns (Unger 1850) or palm fruits (Zablocki 1928). Recently, a very similar type of fruits has been recognized in living Diplopanax stachyanthus Hand.Mazz., native in southern China and Viet Nam. This plant was originally assigned to the Araliaceae (Handel-Mazzetti 1933) but later correctly transferred to the mastixioids by Eyde \& Xiang (1990). The generic identity of both fossil and extant plants is now beyond any question (Mai 1995, Czaja 2003). The type locality of Diplopanax limnophilus is Wieliczka in southern Poland (Middle Badenian, stratotype section - Papp et al. 1978). Kirchheimer (1957) stressed that all mastixioid fossils should be restricted to the Palaeogene and believed that the fossil fruits from Wieliczka had been reworked into younger deposits. Later on, typical fruits of Diplopanax limnophilus were described from a number of sites of the so-called Younger Mastixioid Floras sensu Mai (Mai 1964, Holý 1976, Gregor 1978, Günther \& Gregor 1993). This element belongs to the most typical indicators of the Lower-Middle Miocene Optimum in Central and West Europe. During the cooling phase in the Serravallian (Late Badenian and Sarmatian) Diplopanax limnophilus disappeared from Central Europe. In this respect, its occurrence is very important for the local stratigraphy.

\section{Eomastixia Chandler}

\section{Eomastixia saxonica (Menzel) Holý} Figure 3K-M

1933 Elaeocarpus saxonicus Menzel in Menzel, Gothan \& Sapper, p. 26, pl. 6, fig. 9.

1934 Ganitrocera saxonica (Menzel) Kirchheimer, p. 773, fig. 12.

1976 Eomastixia saxonica (Menzel) Holý, p. 142, pl. 3, figs $1-19$.

Material. - Six woody stone fruits (NM G 8546-8550, one in private coll.).

Description. - Stone fruits widely ovoid and variously flattened, 23-33 $\mathrm{mm}$ long and 20-25 mm wide, bilocular in cross section, epicarp often preserved, thin and smooth, endocarp fairly irregularly and coarsely striated, rugulose.

Notes. - These fruits belong to an extinct genus Eomastixia Chandler (syn. Ganitrocera Kirchheimer) of the Mastixioideae (Late Cretaceous to Late Miocene of Europe - Mai 1993). Holý (1976) assigned very abundant material from the localities Hrádek nad Nisou, Wackersdorf, Merka and Wiesa (late Early Miocene) to Eomastixia saxonica and differentiated it from the similar species E. hildegardis
(Unger) Holý from Cheb and Františkovy Lázně in W Bohemia and Hluboká nad Vltavou in S Bohemia (late Early to Middle Miocene), which is smaller and 1-2 locular (Holý 1976, Mai 1993). Similar records, often called Ganitrocera persicoides (Unger) Kirchheimer or Eomastixia persicoides (Unger) Gregor sensu lato, have been commonly described from the other Younger Mastixioid Floras, e.g., Wiesa, Wackersdorf and Turów (e.g., Mai 1964, Czeczott \& Skirgiełło 1975, Gregor 1978, Günther \& Gregor 1993). Eomastixia saxonica often accompanies Diplopanax and other members of the mastixioids in the Lower-Middle Miocene of Europe (also at Wieliczka Łańcucka-Środoniowa \& Zastawniak 1997). The youngest rare occurrences of E. saxonica are known from the Upper Miocene of Silesia (Gozdnica in Poland - Łańcucka-Środoniowa \& Zastawniak 1993) and Germany (e.g., Wischgrund, Rauno Formation - Mai 1989, 2001). Eomastixia saxonica was found also in the Lower Rhine Basin in the Ville Formation and the lowest part of the Inden Formation at Hambach, W. Germany (Van der Burgh 1987, 1988), probably Middle to early Late Miocene in age ( $c f$. Schäfer et al. 2004). Elsewhere it was replaced during the Late Miocene by another species with larger fruits and a coarser sculpture, Eomastixia holzapfelii (Menzel) Mai, common in the Rhenish refuge area (Mai 1993, 1995).

\section{Conclusions to biostratigraphy and correlation}

As mentioned above, the oldest tektite-bearing coarsegrained sediments in South Bohemia belong to the Vrábče Member (sensu Žebera 1967), which divides the Miocene part of the basins fill into the underlying Mydlovary Formation and the overlying Domanín Formation. Whereas the Mydlovary Formation has been dated by the fauna and flora to the Karpatian- Early Badenian, the gap between the rain of tektites - the Ries event (15-14.5 Ma, i.e., Middle Badenian or Middle Langhian, approx. lower part of NN 5 zone) and the matrix deposits has been variously assessed. Reháková (1969a, b) who established the Domanín Formation on account of the diatom flora assigned it to the Late Badenian to Sarmatian on the basis of the correlation with similar assemblages in the Central Paratethys (locality Nováky in Slovakia - Řeháková 1980) whose age is estimated by palynological correlation (Planderová 1990, MF-7 zone). Because diatoms are not known directly from the psephitic-psammitic tektite-bearing deposits of the Vrábče Member, we cannot verify the correlation and age determination suggested by Řeháková (1980) for the main part of the Domanín Formation. The mammal fauna of Lišov (MN 7-8) from the Domanín Fm. supports the dating into the late Middle Miocene (Fejfar 1989, personal communication 2007). On the other hand, the newly obtained 
mastixioid assemblage from Dobrkovská Lhotka clearly falls into the Early-Middle Miocene Climatic Optimum coming before the Late Badenian/Sarmatian (Serravalian) cooling phase (13.6 Ma). The best equivalent in the Paratethys Province appears the mastixioid assemblage from Wieliczka (Middle Badenian - Wieliczian) sharing the marker species Diplopanax limnophilus (Łańcucka-Środoniowa \& Zastawniak 1993) while the next younger unit, the Floral Assemblage Stare Gliwice - Unterwohlbach (Late Badenian to Sarmatian) almost lacks mastixioids. Floral assemblages (complexes) in the Boreal Provinces in $\mathrm{Eu}-$ rope (Mai 1994, 1995) offer other possible links with those of Wiesa, Kleinleipisch and Klettwitz. Most of them are not independently dated but all can safely be placed into the Early-Middle Miocene Climatic Optimum. The Klettwitz unit (floral zones XI-XII sensu Mai 1967) is best comparable with the Wieliczka - Viehausen Floral Assemblage dated to the Middle Badenian and the mammalian zone MN 6 and includes all elements recovered at Dobrkovská Lhotka. The next younger Floral Assemblage Schipkau (floral zone XIII), which is probably comparable with the flora of Gozdnica in Poland (Gozdnica Series, Pannonian), contains a few rare mastixioids and is characterised by prevailing deciduous "Arctotertiary" elements. Thus the new palaeobotanical data from South Bohemia make possible the Middle Badenian age for the oldest tektite-bearing unit, the Vrábče Member, considered putatively as the basal part of the Domanín Formation, and prove only a short time gap between the rain of tektites and their first re-deposition.

\section{Acknowledgements}

We thank M. Trnka, J. Kaigl and J. Drtina for the donation and loan of the material studied recovered by anonymous collectors. Our thanks are also due to M. Malkovský and O. Fejfar for discussions on the stratigraphy of the South Bohemian Neogene. The latter has kindly supplied the most recent calibration of the time scales for the Paratethys and Tethys Neogene from unpublished works by F. Rögl and M. Harzhauser, Vienna. V. Teodoridis and S. Peikerová have offered us technical assistance with preparing illustrations. The study was sponsored by the Grant Agency of CR (project No. 105/06/0653) and scheme MSM 002162085..

\section{References}

BERGER, W. 1958. Untersuchungen an der obermiozänen (sarmatischen) Flora von Gabbro (Monti Livornesi) in der Toskana. Palaeontographica Italica 51, 1-96.

BOUŠKA, V. 1972. Geology of the moldavite-bearing sediments and the contributions of moldavites. Acta Universitatis Carolinae, Geologica 1972(1), 1-29.

BŮŽEK, Č., ČTYROKÝ, P., FEJFAR, O., KONZALOVÁ, M. \& KVAČEK, Z. 1988. Biostratigraphy of Tertiary coal-bearing deposits of Bo- hemia and Moravia (C.S.R.), 291-305. In PEŠEK, J. \& VOZÁR, J. (eds) Coal-bearing formations of Czechoslovakia. Dionýz Štúr Institute of Geology, Bratislava.

CZAJA, A. 2003. Paläokarpologische Untersuchungen von Taphozönosen des Unter- und Mittelmiozäns aus dem Braunkohlentagebau Berzdorf/Oberlausitz (Sachsen). Palaeontographica, Abteilung B 265, 1-148.

CzeczotT, H. \& SkIRGIEŁŁO, A. 1975. Flora kopalna Turowa koło Bogatyni. 2. Systematyczny opis szszątków roślinnych. Cornaceae. Prace Museum Ziemi 24, 49-55.

ČTYROKÝ, P. \& FEJFAR, O. 1962. Zpráva o nálezu břichonožců a obratlovců v mydlovarském souvrství. Věstník Ústředního ústavu geologického 37, 353-357.

EYDE, R.H. \& XIANG, Q.-Y. 1990. Fossil mastixioid (Cornaceae) alive in eastern Asia. American Journal of Botany 77, 689-692.

FEJFAR, O. 1974. Die Eomyiden und Cricetiden (Rodentia, Mammalia) des Miozäns der Tschechoslowakei. Palaeontographica, Abteilung A 146, 100-180.

FEJFAR, O. 1989. The Neogene vertebrate paleontology sites of Czechoslovakia: A contribution to the Neogene terrestrict biostratigraphy of Europe based on rodents, 211-236. In LINDSAY, E.H., FAHLBUSCH, V. \& MEIN, P. (eds) Proceedings of a NATO Advances Research workshop on European Neogene mammal chronology. Plenum Press, New York.

Fischer, T.C. \& ButzMAnN, R. 2006. The Pliocene macro- and microflora of lacustrine sediments from Meleto (Valdarno, N. Italy) and its ecological, palaeobiogeographical and climatic interpretation. Cainozoic Research 5, 71-88.

Genter, W., KLeinMan, B. \& WAGner, G.A. 1967. New K-Ar and fission-track ages of impact glasses and tektites. Earth and Planetary Science Letters 2, 83-86.

Genter, W., Storzer, D. \& WAgner, G.A. 1969. New fission track ages of tektites and related glasses. Geochemica et Cosmochimica Acta 27, 1075-1081.

GREGOR, H.-J. 1978. Die miozänen Frucht- und Samen-Floren der Oberpfälzer Braunkohle. I. Palaeontographica, Abteilung B 167, 8-103.

GÜNTHER, T. \& GREGOR, H.-J. 1993. Computeranalyse neogener Frucht- and Samenfloren Europas. Documenta Naturae 50, 4, 1-190.

HANDEL-MazZeTti, H. 1933. Planatae novae Chingianae. III. Sinensia 3, 185-198.

HEER, O. 1855. Flora Tertiaria Helvetiae. I.J. Wurster et comp., Winterthur.

HoLÝ, F. 1976. Representatives of the family Mastixiaceae Calestani 1905 in the Bohemian Tertairy. Acta Musei nationalis Pragae, Series $B$ - historia naturalis 31(3-5), 123-147.

HuBER, K.H. 2003. Some field observations and remarks on the Gmünd Beds of the nordwestern Waldviertel Region (Lower Austria). Jahrbuch der geologischen Bundesanstalt 143, 543-566.

KNOBloch, E. \& KVAČEK, Z. 1996. Miozäne Floren der südböhmischen Becken. Sborník geologických věd, Paleontologie 33, 39-77.

KIRCHHEIMER, F. 1934. Neue Ergebnisse und Probleme paläobotanischer Braunkohlenforschungen. Braunkohle 33, 45-46.

KIRCHHEIMER, F. 1941. Bemerkenswerte Funde der Mastixioideen-Flora. Braunkohle 40, 610-617.

KIRCHHEIMER, F. 1942. Zur Kenntnis der Alttertiärenpflanzen von Wiesa (Sachsen). Planta 32, 418-446.

KIRCHHEIMER, F. 1957. Die Laubgewächse der Braunkohlenzeit. VEB Wilhelm Knapp Verlag, Halle (Saale). 
ŁAŃCUCKA-ŚRODONIOWA, M. \& ZASTAWNIAK, E. 1993. A supplementary note on the Upper Miocene flora of Gozdnica in Lower Silesia (SW Poland). Acta Palaeobotanica 33, 267-293.

ŁAŃCUCKA-ŚRODONIOWA, M. \& ZASTAWNIAK, E. 1997. The Middle Miocene flora of Wieliczka. Revision of Jan Zablocki's collection. Acta Palaeobotanica 37, 17-49.

LUDWIG, R. 1857. Fossile Pflanzen aus der jüngsten Wetterauer Braunkohle. Palaeontographica 5, 81-109.

MÄDLER, K. 1939. Die pliozäne Flora von Frankfurt am Main. Abhandlungen der Senckenbergischen naturforschenden Gesellschaft 446, 53-125.

MAI, D.H. 1964. Die Mastixioideen-Floren im Tertiär der Oberlausitz. Paläontologische Abhandlungen 2(1), 1-192.

MAI, D.H. 1967. Die Florenzonen, der Florenwechsel und die Vorstellung über den Klimaablauf im Jungtertiär der Deutschen Demokratischen Republik. Abhandlungen des Zentralen geologischen Instituts 10, 55-82.

MAI, D.H. 1986. Über Typen und Originale tertiärer Arten von Pinus L. (Pinaceae) in mitteleuropäischen Sammlungen - Ein Beitrag zur Geschichte der Gattung in Europa. Feddes Repertorium 97, 571-805.

MAI, D.H. 1989. Die fossile Flora des Blättertons von Wischgrund und anderer gleichaltrigen Fundstellen der Klettwitzer Hochfläche. II. Natur und Landschaft im Bezirk Cottbus 11, 3-44.

MAI, D.H. 1993. On the extinct Mastixiaceae (Cornales) in Europe. Geophytology 23, 53-63.

MAI, D.H. 1994. Florenzonen und Klimawechsel im Tertiär der Lausitz. Brandenburgische geowissenchaftliche Beiträge 1, 90-99.

MAI, D.H. 1995. Tertiäre Vegetationsgeschichte Europas. Gustav Fischer Verlag, Jena.

MAI, D.H. 1999. Die untermiozänen Floren aus der Spremberger Folge und dem 2. Flözhorizont in der Lausitz. Teil I.: Farnpflanzen, Koniferen und Monokotyledonen. Palaeontographica, Abteilung B 250, 1-76.

MAI, D.H. 2001. Die mittelmiozänen und obermiozänen Floren aus der Meuroer und Raunoer Folge in der Lausitz. Teil II: Dikotyledones. Palaeontographica Abt. B 257, 35-174.

MAI, D.H. \& KNOBLOCH, E. 1986. Monographie der Früchte und Samen in der Kreide von Mitteleuropa. Rozpravy Ústředního ústavu geologického 47, 1-221.

MALECHA, A. 1985. Jihočeské pánve, 51-63. In CHÁBERA, S. (ed.) Jihočeská vlastivěda. Řada A - Přírodní vědy: Neživá př́roda. Jihočeské nakladatelství České Budějovice.

MaleCha, A., ŠPINAR, Z., BOŘKOVÁ-GABRIELOVÁ, N., MRÁZEK, A., NĚmejc, F., PACltová, B., Řeháková, Z. \& SlánSKÁ, J. 1962. Nové dělení a označení stratigrafických jednotek jihočeských pánví. Věstník Ústředního ústavu geologického 37, $161-170$.

MALKOVSKÝ, M. 1995. Některé problémy chronostratigrafického členění terciéru Českého masívu. Knihovnička Zemní plyn a nafta 16, 25-36.

MANCHESTER, S.R. 1987. The fossil history of the Juglandaceae. Monographs in systematic botany from the Missouri Botanical Garden 21, 1-137.

MenZEL, P., GOTHAN, W. \& SAPPER, I. 1933. Neues zur Tertiärflora der Niederlausitz. Arbeiten aus dem Institut für Paläobotanik und Petrographie der Brennsteine 3, 1-44.

NĚMEJC, F. 1956. Paleobotanická studie k otázce stratigrafie uloženin jihočeské pánve. (A palaeobotanical study of the question of the stratigraphy of the deposits of the South Bohemian Basin). Sborník Ústředního ústavu geologického, Oddíl paleontologický 22, 335-377.

NĚMEJC, F. 1962. Paleobotanicko-stratigrafické výzkumy v jihočeských pánvích. Zprávy o geologických výzkumech v roce 1961, 235-236.

PACLTOVÁ, B. 1961. Některé rostlinné mikrofosilie ze sladkovodních uloženin svrchní křídy (senon) v jihočeských pánvích 1. Sborník Ústředního ústavu geologického, Oddíl palaeontologický 26, 47-102.

PACLTOVÁ, B. 1963. Palynologická charakteristika ledenického souvrství (svrchní pliocén) v tř̌eboňské pánvi v jižních Čechách. Sborník geologických věd, Geologie 2, 7-55.

PAPP, A., Cicha, I., SENEŠ, J. \& STEINIGER, F. 1978. M 4 Badenien (Moravien, Wielicien, Kosovien). Chronostratigraphie und Neostratotypen. Miozän der Zentralen Paratethys 6, 1-594.

PlanderovÁ, E. 1990. Miocene microflora of Slovak Central Paratethys and its biostratigraphical significance. Dionýz Štúr Institute of Geology, Bratislava.

ŘEHÁKOVÁ, Z. 1963. Jihočeské pánevní sedimenty ve světle diatomových analýz. Věstník Ústředního ústavu geologického 38, 311-323.

ŘEHÁKOVÁ, Z. 1969a. Entwicklung der Diatomeensedimentation im Neogen der südböhmischen Becken. Mitteillung des internationalen Vereins für Limnologie 17, 259-261.

ŘEHÁKOVÁ, Z. 1969b. Beitrag zur stratigraphischen Gliederung des Neogens der südböhmischen Becken. Věstník Ústředního ústavu geologického 44, 307-309.

ŘEHÁKOVÁ, Z. 1980. Süsswasserdiatomeenflora des oberen Miozäns in der Tschecoslowakei. Sborník geologických věd, Paleontologie 23, 83-184.

SCHÄFER, A., UtesChER, T. \& MÖRS, T. 2004. Stratigraphy of the Cenozoic Lower Rhine Basin, northwestern Germany. Newsletters in Stratigraphy 40, 73-110.

SLÁNSKÁ, J. 1974. Continental Cretaceous and Tertiary sedimentation in the South Bohemian Basins, Czechoslovakia. Neues Jahrbuch für Geologie und Paläontologie, Abhandlungen 146, 385-406.

ŠEVČíK, J. 1980. Závěrečná zpráva úkolu Besednice 01872402 surovina: vltavínonosné šěrkopísky. MS Geoindustria, Praha.

UNGER, F. 1841-1847. Chloris protogaea. Beiträge zur Flora der Vorwelt. W. Engelmann, Leipzig.

Unger, F. 1850. Die Pflanzenreste im Salzstock Wieliczka. Denkschriften der Kaiserlichen Akademie der Wissenschaften, mathematisch-naturwissenschaftliche Classe 1, 311-322.

VAN DER BURGH, J. 1987. Miocene floras in the lower Rhenish Basin and their ecological interpretation. Review of Palaeobotany and Palynology 52, 299-366.

VAN DER BURGH, J. 1988. Some local floras from the Neogene in the lower Rhenish basin. Tertiary Research 9, 181-212.

VRÁNA, S. Ed. 1980. Vysvětlivky k základní geologické mapě ČSSR $1: 25$ 000, 22-44. Hluboká nad Vltavou. Ústřední ústav geologický, Praha.

ZABLOCKI, J. 1928. Tertiäre Flora des Salzlagers von Wieliczka 1. Acta Societatis Botanicae Poloniae 5(2), 174-208.

ŽEBERA, K. 1967. Moldavite-bearing sediments between Koroseky and Holkov in South Bohemia. Věstník Ústředního ústavu geologického 42, 327-337. 